\title{
Analysis of the proteome of human airway epithelial secretions
}

Mehboob Ali ${ }^{1,3+}$, Erik P Lillehoj ${ }^{2 \dagger}$, Yongsung Park ${ }^{1}$, Yoshiyuki Kyo ${ }^{1}$, K Chul Kim $^{1 *}$

\begin{abstract}
Background: Airway surface liquid, often referred to as mucus, is a thin layer of fluid covering the luminal surface that plays an important defensive role against foreign particles and chemicals entering the lungs. Airway mucus contains various macromolecules, the most abundant being mucin glycoproteins, which contribute to its defensive function. Airway epithelial cells cultured in vitro secrete mucins and nonmucin proteins from their apical surface that mimics mucus production in vivo. The current study was undertaken to identify the polypeptide constituents of human airway epithelial cell secretions to gain a better understanding of the protein composition of respiratory mucus.

Results: Fifty-five proteins were identified in the high molecular weight fraction of apical secretions collected from in vitro cultures of well-differentiated primary human airway epithelial cells and isolated under physiological conditions. Among these were MUC1, MUC4, MUC5B, and MUC16 mucins. By proteomic analysis, the nonmucin proteins could be classified as inflammatory, anti-inflammatory, anti-oxidative, and/or anti-microbial.

Conclusions: Because the majority of the nonmucin proteins possess molecular weights less than that selected for analysis, it is theoretically possible that they may associate with the high molecular weight and negatively charged mucins to form a highly ordered structural organization that is likely to be important for maintaining the proper defensive function of airway mucus.
\end{abstract}

\section{Background}

Mucins are a heterogeneous group of polydisperse and high molecular weight $\mathrm{O}$-glycosylated proteins, ranging from 300,000 to $>1 \times 10^{7} \mathrm{Da}[1]$. Mucin genes encode polypeptide monomers that are synthesized as rod-shape apomucin cores and are post-translationally modified by exceptionally abundant and terminally sialylated glycan moieties. Mucins are secreted or inserted to the apical surface membrane of epithelial cells via a membranespanning hydrophobic domain [2,3]. Secreted mucins constitute the most abundant glycoprotein component of mucus, a gel-like substance that covers all wet-surfaced epithelia, including those of the respiratory, gastrointestinal, and genitourinary tracts [4-7]. Eighteen mucin (MUC) genes have been cloned, 12 of which are expressed in the respiratory tract [3]. Airway secreted

\footnotetext{
* Correspondence: kckim@temple.edu

† Contributed equally

'Department of Physiology and Lung Center, Temple University School of Medicine, Philadelphia, PA, USA

Full list of author information is available at the end of the article
}

mucins (MUC2, 5AC, 5B, 7, 8, 11, 13, 19, and 20) are produced by goblet cells on the surface epithelium and mucous cells from sub-mucosal glands [4,5,7]. Membrane-associated mucins in the airways include MUC1, MUC4, and MUC16. Mucin gene and protein structures, goblet cell mucin secretion and hypersecretion in airway diseases as well as the regulation of goblet cell hyperplasia have been well-documented in the literature [7-9]. However, the complex interactions between mucins and other protein components of airway mucus remain to be elucidated.

In vitro cultures of human and animal airway epithelial cells have been used to characterize mucin production under various experimental conditions. Human cell cultures from tracheal glands were reported to express a mixed serous and mucous phenotype $[10,11]$. Normal and cystic fibrosis cells from human tracheal glands isolated by the explant/outgrowth procedure secreted high molecular weight mucin-like glycoproteins and expressed the MUC2 gene [12]. The development and characterization of primary cell cultures from tracheal 
surface epithelium [13] that were highly enriched for secretory cells allowed the first identification of authentic airway mucins that were produced in vitro [14]. Confluent cultures of hamster tracheal epithelial cells cultured on a type I collagen gel synthesized and secreted high molecular weight glycoconjugates which eluted in the void volume upon Sepharose CL-4B column chromatography $[14,15]$. Biochemical analysis of these mucous glycoproteins showed both size and charge microheterogeneities that were remarkably similar to those of mucins produced in vivo.

The in vitro model of mucin production by airway epithelial cell cultures first established in hamsters was subsequently extended to guinea pig and human airway epithelium [16,17]. Proteomic studies have revealed that the protein composition of in vitro human airway epithelial cell secretions is particularly complex. Candiano et al. [18] used a two-dimensional SDS-PAGE/proteomics approach to identify the proteins secreted by in vitro cultures of polarized monolayers of human airway epithelial cells at resting and following stimulation with IL-4, IL$1 \beta$, TNF- $\alpha$, or IFN- $\gamma$. Approximately 175 polypeptides were identified, among which were immune-related proteins, structural proteins, proteases, and protease inhibitors. Comparisons between treated and untreated conditions showed that the expression of several proteins was significantly modified by the different cytokines. Kesimer et al. [19] identified 134 proteins from apical secretions of primary airway epithelial cells, with 84 proteins $(62.7 \%)$ being common with the proteins identified in in vivo human tracheobronchial sputum. Separation of the proteins by density gradient ultracentrifugation in the presence of $4 \mathrm{M}$ guanidine hydrochloride identified 29 proteins that were present in the high-density, mucinrich fraction. The nonmucin proteins in this fraction were also present in the lower-density pool, suggesting to the authors that they associated and copurified with the mucins. However, given that the proteins were isolated under denaturing conditions, the current study was conducted to identify mucin-associated proteins in in vitro human airway epithelial cell secretions isolated under more physiological conditions.

\section{Methods}

\section{Preparation of human airway epithelial cell secretions (hAECS)}

Primary normal human bronchial epithelial (NHBE) cells and culture media were purchased from MatTek Corp. (Ashland, MA). Air-liquid interface (ALI) cell cultures were maintained according to the manufacturer's protocol. The cells were seeded and incubated for 2 days at $37^{\circ} \mathrm{C}$ as submerged cultures before ALI culture was initiated. At confluence, the apical surface of the culture was washed with culture medium and the collected medium was referred to as hAECS. hAECS were collected daily for 5 days from multiple independent cultures of NHBE cells reflecting different cell donors and were pooled so that the data could not be attributed to artifacts of a single donor's genotype. Pooled samples were dialyzed against 100-fold volume of distilled water at $4{ }^{\circ} \mathrm{C}$ for 2 days to approximately $5 \mathrm{mOsm} / \mathrm{L}$, lyophilized, and stored at $-80^{\circ} \mathrm{C}$.

\section{Gel filtration chromatography}

Approximately $1.80 \mathrm{mg}$ of hAECS protein in $2.5 \mathrm{ml}$ was separated on a Sepharose CL-4B gel filtration column $(3.0 \times 50 \mathrm{~cm})$, pre-calculated for the void volume $\left(\mathrm{V}_{0}\right)$ and total volume $\left(\mathrm{V}_{\mathrm{t}}\right)$ fractions with dextran blue and phenol red respectively. Proteins were applied and eluted in PBS, pH 7.2 with elution monitored by absorbance at $280 \mathrm{~nm}\left(\mathrm{~A}_{280}\right)$. The $\mathrm{V}_{0}$ fractions containing high molecular weight mucins and associated proteins were collected, assayed for carbohydrate content by reaction with Periodic acid-Schiff reagents, and stored at $-20^{\circ} \mathrm{C}$ until use.

\section{Periodic acid-Schiff carbohydrate assay}

The Periodic acid-Schiff staining kit from Sigma (St. Louis, MO) was used to determine carbohydrate content according to the manufacturer's instructions. Briefly, 180 $\mu \mathrm{l}$ of sample was added to wells of a 96-well plate, followed by the addition of $20 \mu \mathrm{l}$ of periodic acid solution, incubation at $37^{\circ} \mathrm{C}$ for $1 \mathrm{hr}$, addition of $20 \mu \mathrm{l}$ of Schiff's reagent, and incubation at room temperature for 30 min. $A_{555}$ was measured using a spectrophotometer.

\section{MUC5AC Westen blot assay}

Samples were diluted in 1:4 in $40 \mathrm{mM}$ Tris-acetate, $\mathrm{pH}$ 8.0 containing $40 \%$ glycerol and $0.8 \%$ bromophenol blue and heated at $100^{\circ} \mathrm{C}$ for $5 \mathrm{~min}$. Samples were electrophoresed in $1.0 \%$ agarose gels $(12 \times 12 \mathrm{~cm})$ using $40 \mathrm{mM}$ Tris-acetate, $\mathrm{pH} 8.0$ containing $1.0 \mathrm{mM}$ EDTA and $0.1 \%$ $\mathrm{SDS}$ at $30 \mathrm{~V}$ for $20 \mathrm{hr}$ at room temperature. After electrophoresis, the agarose gels were incubated with transfer buffer (0.06 M sodium citrate, $\mathrm{pH}$ 7.0, 0.6 M NaCl) for $30 \mathrm{~min}$ and proteins were transferred to PVDF membrane overnight by the capillary blotting. The membrane was blocked with PBS containing 0.5\% Tween 20 for 1 $\mathrm{hr}$, sequentially incubated overnight with primary antiMUC5AC monoclonal antibody (1:2,000; 45 M1, GenWay Biotech, San Diego, CA), $1 \mathrm{hr}$ with goat anti-mouse IgG secondary antibody (1:10,000; KPL, Gaithersburg, $\mathrm{MD}$ ), and enhanced chemiluminescence substrate (Amersham GE Healthcare, Piscataway, NJ).

\section{Proteomics analysis TCA precipitation of $V_{o}$ fractions}

$\mathrm{V}_{0}$ fractions were precipitated by addition of a 4-fold volume of TCA overnight at $4^{\circ} \mathrm{C}$. Samples were 
centrifuged at $15,000 \times \mathrm{g}$ for $15 \mathrm{~min}$ at $4^{\circ} \mathrm{C}$, the pellets were resuspended in $200 \mu \mathrm{l}$ of acetone at $-20^{\circ} \mathrm{C}$, centrifuged, and air-dried.

\section{One-dimensional SDS-polyacrylamide gel electrophoresis}

TCA precipitated and acetone washed $V_{0}$ fractions of hAECS were resuspended in a minimum volume of $30 \mathrm{mM}$ Tris- $\mathrm{HCl}, \mathrm{pH}$ 8.5-9.0 containing $2 \mathrm{M}$ thiourea, 7 $\mathrm{M}$ urea, and $4 \%$ CHAPS. Thirty $\mu \mathrm{g}$ of protein was diluted in an equal volume of SDS-PAGE sample loading buffer $(120 \mathrm{mM}$ Tris- $\mathrm{HCl}, \mathrm{pH} 6.8$ containing $20 \%$ glycerol, 4\% SDS, $200 \mathrm{mM}$ DTT, and 0.01\% bromophenol blue). Samples were resolved on one-dimensional $12 \%$ SDS-PAGE gels at $20 \mathrm{~mA}$ for $30 \mathrm{~min}$ and $50 \mathrm{~mA}$ until the bromophenol dye front reached the bottom of gel. Gels were silver-stained and photographed.

\section{Nano-LC-IT MS}

Gel slices obtained along the entire length of the SDSPAGE gel were reduced with $10 \mathrm{mM}$ DTT in $50 \mathrm{mM}$ $\mathrm{NH}_{4} \mathrm{HCO}_{3}$ for $30 \mathrm{~min}$ at $37^{\circ} \mathrm{C}$ and alkylated with $50 \mathrm{mM}$ iodoacetamide in $50 \mathrm{mM} \mathrm{NH}_{4} \mathrm{HCO}_{3}$ for $30 \mathrm{~min}$ at room temperature in the dark. Gel slices were destained with $50 \%(\mathrm{v} / \mathrm{v})$ acetonitrile in $50 \mathrm{mM}$ $\mathrm{NH}_{4} \mathrm{HCO}_{3}$, dehydrated with acetonitrile, and $40 \mathrm{ml}$ of $12.5 \mathrm{mg} / \mathrm{ml}$ trypsin in $50 \mathrm{mM} \mathrm{NH} \mathrm{NCO}_{3}$ was added to cover the gel pieces. Following overnight trypsin digestion, peptides released into solution were desalted, dried by vacuum centrifugation, and resolubilized in $30 \mathrm{ml}$ of $0.1 \%$ (vol/vol) trifluoroacetic acid. The sample was loaded onto a $2 \mathrm{mg}$ capacity peptide trap (CapTrap; Michrom Bioresources, Auburn, CA) prior to separation on a C-18 reversed-phase HPLC capillary column $(15 \mathrm{~cm}, 75 \mathrm{~mm}$, Agilent, Santa Clara, CA) at $300 \mathrm{nl} / \mathrm{min}$ delivered by an Agilent 1100 LC pump. A mobile-phase gradient was run using mobile phases A ( $1 \%$ acetonitrile/ $0.1 \%$ formic acid) and $\mathrm{B}(80 \%$ acetonitrile $/ 0.1 \%$ formic acid) from 0 to 10 min with $0-15 \% \mathrm{~B}, 10-60$ min with $15-60 \% \mathrm{~B}$, and 60-65 min with 60-100\% B. Eluted peptides were analyzed by nanoelectrospray ionization (ESI) tandem mass spectrometry (MS) using a HCT Ultra ion trap mass spectrometer (Bruker Daltonics Inc., Billerica, MA). ESI was delivered using distal-coating spray Silica tip (ID 20 mM, tip inner ID $10 \mathrm{mM}$, New Objective, Woburn, MA) at a spray voltage of $-1300 \mathrm{~V}$. Using automatic switching between MS and MS/MS modes, MS/MS fragmentation was performed on the two most abundant ions on each spectrum using collision-induced dissociation with active exclusion (excluded after two spectra and released after 2 min). The entire system was controlled by HyStar 3.1 software.

\section{Data analysis}

Mass spectra processing was performed with Data Analysis 3.3 software and the generated peak list was submitted to an in-house Mascot (Matrix Science, Boston, MA) search engine (version 2.2) for searching against the Swiss-Prot protein database (version 56.6 containing 410,518 sequences). Mascot search parameters were set as follows: taxonomy human, trypsin enzyme with maximal 1 missed cleavage, cysteine carboxymethylation as fixed modification, methionine oxidation as variable modifications, and 0.30 Da mass tolerance for precursor peptide ions and 0.4 Da for MS/MS fragment ions. All peptides matches were filtered with an ion score cutoff of 10. The following criteria were used for protein identification: one peptide with ion score 50 or higher, two or more peptides with one ion score higher than 31 $(\mathrm{p}<0.05)$ and one ion score 20 or higher, and molecular weight match between theoretical and experimental values applied for proteins with Mascot scores less than 70. Protein identifications were only accepted and reported as distinct hits if they were based on at least one unique peptide that passed probability validation. Under these criteria, no false positive matches were found when searched against a reversed-decoy SwissProt database. Identified proteins were analyzed for molecular and biological function using the Panther protein database [20] and literature search using PubMed.

\section{Results}

\section{Gel filtration chromatography of hAECS}

Figure 1 shows the Sepharose CL-4B gel filtration profile of hAECS collected from the apical surface of in vitro cultures of primary NHBE cells cultured at an ALI. Two peaks of protein elution were detected by $A_{280}$, the $V_{0}$ (fraction 18) and the $V_{t}$ (fraction 41) (denoted by solid line). The periodic acid-Schiff assay confirmed the presence of glycoproteins in the $V_{0}$ fractions (denoted by dotted line).

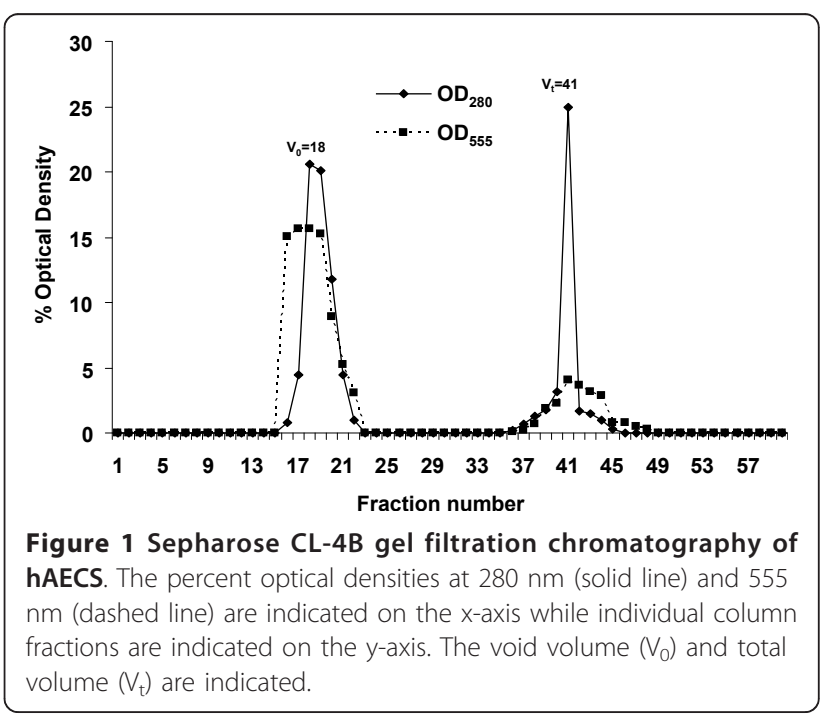




\section{Gel electrophoretic analysis of hAECS proteins}

Silver staining of hAECS proteins in the Sepharose CL$4 \mathrm{~B} \mathrm{~V}_{0}$ fraction that were resolved by one-dimensional SDS-PAGE showed the presence of multiple protein bands (Figure 2). Most of the proteins bands were $<75 \mathrm{kDa}$ with a diffuse area of staining at $>250 \mathrm{kDa}$.

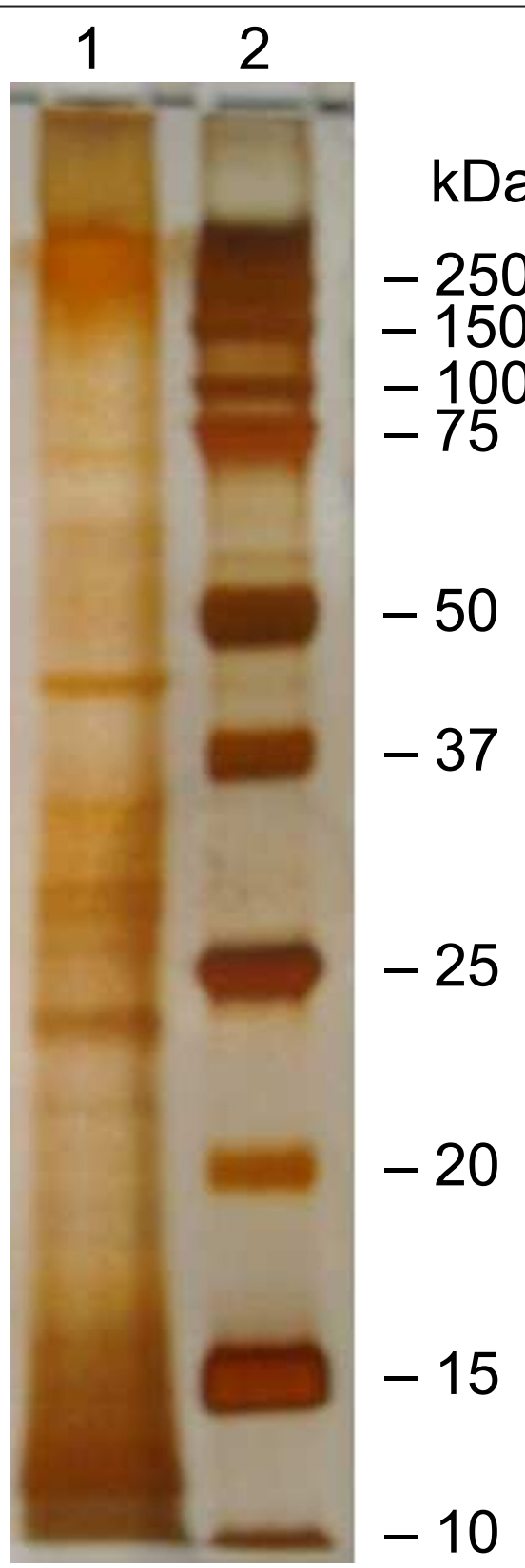

Figure 2 One-dimensional SDS-polyacrylamide gel electrophoresis of $\mathrm{V}_{\mathbf{0}}$ fraction from gel filtration chromatography. Proteins were separated on a $12 \%$ gel under reducing conditions and visualized by silver staining. Lane 1, hAECS sample. Lane 2 , prestained molecular weight marker proteins. Molecular weights in $\mathrm{kDa}$ are indicated on the right.

\section{Protein identification by nano-LC-IT MS}

The hAECS sample resolved by gel filtration chromatography and SDS-PAGE was divided into ten $0.5 \mathrm{~cm}$ gel slices, each of which was processed as described in the Methods. Fifty-five proteins were identified (Table 1). Among these were MUC1, MUC4, MUC5B, and MUC16 in the high molecular weight region $(>250 \mathrm{kDa})$ of the acrylamide gel. While MUC5AC was not identified by proteome analysis, this mucin was readily detected by Western blotting of hAECS (Figure 3). The molecular (Figure 4) and biological (Figure 5) functions of the identified proteins were made using the Panther protein database search engine. According to molecular function analysis, most of the identified proteins were classified as regulatory molecules $(20.0 \%)$, calcium binding proteins $(16.4 \%)$, transfer/carrier proteins $(10.9 \%)$, and defense/immunity-related proteins (10.9\%). According to biological function analysis, the majority of the identified proteins belonged to the defense/immunity (32.7\%), protein metabolism and modification (23.6\%), and signal transduction (16.4\%) categories. Based on a combined search of the published literature and the Panther protein database analysis, the identified proteins were grouped into 4 major functional subgroups, namely inflammatory, anti-inflammatory, anti-oxidant, and antimicrobial (Figure 6).

\section{Discussion}

Among the 55 proteins that were identified in the high molecular weight fraction of hAECS from in vitro cultures of primary NHBE cells collected under physiological conditions, 43 (78.2\%) were unique to this study and $12(21.8 \%)$ were common to proteins identified in the mucin-rich apical secretions isolated under denaturing conditions by Kesimer et al. [19]. The shared proteins of the two studies are: MUC1, MUC4, MUC5B, MUC16, CD59, complement C3, clusterin, glutathione S-transferase, lactotransferrin, long palate, PLUNC (palate, lung and nasal epithelial clone) protein, LPLUNC1 (long PLUNC), and the polymeric immunoglobulin receptor. All of the proteins unique to our study comprise important inflammatory, anti-inflammatory, anti-microbial and/or anti-oxidant components that are elicited by the respiratory tract in response to exposure to infectious or injurious insults [21]. On the other hand, among the proteins that were identified by Kesimer et al. [19] but not in this study are alpha-defensin 1 and secretory leukocyte peptidase inhibitor (SLPI), both of which are thought to have broad-spectrum antibiotic activities [22].

While it is tempting to speculate that the proteins we identified may form a physiologically relevant association with mucins, it is important to emphasize that they may or may not be actively secreted by the cells, or may 
Table 1 Proteins identified in the $\mathrm{V}_{0}$ fraction of hAECS following SDS-PAGE

\begin{tabular}{|c|c|c|c|c|c|}
\hline Gene Name & Protein Name & Gel Slice $^{a}$ & Ion Score ${ }^{\text {b }}$ & Mol Wt $(\mathrm{Da})^{\mathrm{c}}$ & Matches $^{d}$ \\
\hline A2AP_HUMAN & Alpha-2-antiplasmin & $3-4$ & 57 & 54,531 & 1 \\
\hline A2MG_HUMAN & Alpha-2-macroglobulin & 2 & 134 & 163,175 & 3 \\
\hline AACT_HUMAN & Alpha-1-antichymotrypsin & 4 & 240 & 47,621 & 6 \\
\hline ANXA1_HUMAN & Annexin A1 & 5 & 245 & 38,690 & 7 \\
\hline ANXA2_HUMAN & Annexin A2 & 5 & 539 & 38,580 & 14 \\
\hline CEAM5_HUMAN & Carcinoembryonic antigen-related cell adhesion molecule 5 & $2-3$ & 75 & 76,748 & 1 \\
\hline CATD_HUMAN & Cathepsin D & 4 & 102 & 44,524 & 6 \\
\hline CD59_HUMAN & CD59 glycoprotein & $9-10$ & 121 & 14,168 & \\
\hline CERU_HUMAN & Ceruloplasmin & 2 & 85 & 122,128 & \\
\hline CLUS_HUMAN & Clusterin & $3-4$ & 167 & 52,461 & 3 \\
\hline CFAH_HUMAN & Complement factor $\mathrm{H}$ & 2 & 58 & 139,005 & 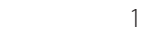 \\
\hline CFAl_HUMAN & Complement factor I & 3 & 64 & 65,677 & 1 \\
\hline CO3_HUMAN & Complement C3 & 1 & 1,453 & 187,030 & 38 \\
\hline CYTB_HUMAN & Cystatin-B & 10 & 91 & 11,133 & 2 \\
\hline DDEF2_HUMAN & Development and differentiation-enhancing factor 2 & 2 & 45 & 111,581 & 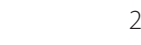 \\
\hline ENOA_HUMAN & Alpha-enolase (Enolase 1) & 4 & 110 & 47,139 & 2 \\
\hline EZRI_HUMAN & Ezrin & 3 & 105 & 69,370 & 2 \\
\hline FBLN3_HUMAN & EGF-containing fibulin-like extracellular matrix protein 1 & $3-4$ & 39 & 54,604 & 1 \\
\hline FETUA_HUMAN & Alpha-2-HS-glycoprotein (Fetuin A) & 5 & 142 & 39,300 & ? \\
\hline ALDOA_HUMAN & Fructose-bisphosphate aldolase A & 5 & 76 & 39,395 & 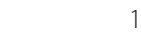 \\
\hline LG3BP_HUMAN & Galectin-3-binding protein & 3 & 120 & 65,289 & 5 \\
\hline GELS_HUMAN & Gelsolin & 2 & 293 & 85,644 & 10 \\
\hline G3P_HUMAN & Glyceraldehyde-3-phosphate dehydrogenase & 5 & 187 & 36,030 & 4 \\
\hline GSTM1_HUMAN & Glutathione S-transferase Mu 1 & 6 & 128 & 25,695 & 6 \\
\hline GSTM2_HUMAN & Glutathione S-transferase Mu 2 & 6 & 168 & 25,728 & 6 \\
\hline GSTM3_HUMAN & Glutathione S-transferase Mu 3 & 6 & 180 & 26,542 & 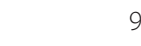 \\
\hline GSTM5_HUMAN & Glutathione S-transferase Mu 5 & 6 & 172 & 25,658 & . \\
\hline GSTMP1_HUMAN & Glutathione S-transferase P & $6-7$ & 53 & 23,341 & 1 \\
\hline HBA_HUMAN & Hemoglobin subunit alpha & 9 & 56 & 15,248 & 1 \\
\hline INADL_HUMAN & InaD-like protein & 1 & 53 & 196,247 & 1 \\
\hline ITIH2_HUMAN & Inter-alpha-trypsin inhibitor heavy chain $\mathrm{H} 2$ & 2 & 112 & 106,370 & 2 \\
\hline LDHA_HUMAN & L-lactate dehydrogenase A chain & 5 & 131 & 36,665 & 3 \\
\hline LDHB_HUMAN & L-lactate dehydrogenase B chain & 5 & 114 & 36,615 & 2 \\
\hline TRFL_HUMAN & Lactotransferrin (Lactoferrin) & 2 & 100 & 78,132 & 7 \\
\hline LPLC1_HUMAN & Long palate, lung and nasal epithelium clone protein 1 & $3-4$ & 1,188 & 52,408 & 36 \\
\hline MUC1_HUMAN & Mucin-1 & 1 & 131 & 121,999 & 3 \\
\hline MUC4_HUMAN & Mucin-4 & 1 & 131 & 231,440 & 3 \\
\hline MUC5B_HUMAN & Mucin-5B & 1 & 1,207 & 590,122 & 27 \\
\hline MUC16_HUMAN & Mucin-16 & 1 & 56 & $2,351,813$ & 2 \\
\hline NGAL_HUMAN & Neutrophil gelatinase-associated lipocalin & 7 & 344 & 22,574 & 12 \\
\hline PRDX1_HUMAN & Peroxiredoxin-1 & 7 & 125 & 22,096 & 4 \\
\hline PEDF_HUMAN & Pigment epithelium-derived factor & 4 & 187 & 46,313 & 5 \\
\hline PIGR_HUMAN & Polymeric immunoglobulin receptor & 2 & 999 & 83,232 & 24 \\
\hline PLUNC_HUMAN & Protein PLUNC & 6 & 438 & 26,696 & 13 \\
\hline S100P_HUMAN & Protein S100-P (S100 calcium binding protein P) & 10 & 118 & 10,393 & 3 \\
\hline S10A6_HUMAN & Protein S100-A6 (S100 calcium binding protein A6) & 10 & 48 & 10,173 & 2 \\
\hline S10A8_HUMAN & Protein S100-A8 (S100 calcium binding protein A8) & 10 & 61 & 10,828 & 2 \\
\hline S10AB_HUMAN & Protein S100-A11 (S100 calcium binding protein A11) & 10 & 41 & 11,733 & 1 \\
\hline S10AG_HUMAN & Protein S100-A16 (S100 calcium binding protein A16) & 10 & 42 & 11,794 & 1 \\
\hline RAB1A_HUMAN & Ras-related protein Rab-1A & $7-8$ & 100 & 22,663 & 2 \\
\hline RAB1B_HUMAN & Ras-related protein Rap-1B & $7-8$ & 118 & 20,812 & \\
\hline
\end{tabular}


Table 1 Proteins identified in the $\mathbf{V}_{\mathbf{0}}$ fraction of hAECS following SDS-PAGE (Continued)

\begin{tabular}{llrr}
\hline TIMP1_HUMAN & Tissue inhibitor of metalloproteinase 1 & 7 & 74 \\
UB2D2_HUMAN & Ubiquitin-conjugating enzyme E2 D2 & 9 & 40 \\
UB1Q_HUMAN & Ubiquitin (ribosomal protein S27a) & 10 & 16,724 \\
VTDB_HUMAN & Vitamin D-binding protein & $3-4$ & 3,560 \\
\hline
\end{tabular}

${ }^{a}$ SDS-PAGE gel slice number (1 [top] - 10 [bottom]) from which the protein was isolated.

${ }^{\mathrm{b}}$ Ion Score, probability value that an observed peptide match is a true match; cuttoff value $=10$.

'Theoretical molecular weight from Swiss-Prot database.

${ }^{\mathrm{d}}$ Number of tryptic peptides generated that match the mass of theoretical trypsin peptides.

simply constitute membrane-bound proteins that passively adhere to the mucins, although other membrane components, such as lipids, were not identified. Further, given that the apical washings were dialyzed against distilled water, we cannot exclude the possibility that some of the identified polypeptides are intracellular proteins from sloughed cells and thus are not necessarily components of airway mucus. We also cannot rule out that



our results may not reflect the proteome of in vivo airway lining fluid given the probable contributions of other cell types and blood-borne proteins that were not present in the NHBE cell cultures. However, the contribution of the cell culture media appears negligible since serum albumin, the most abundant protein in culture media, was not identified in the current analysis.

The presence of MUC1, MUC4, MUC5B, and MUC16 in in vitro hAECS confirms prior studies of mucin glycoprotein secretion by human and animal airway epithelial cell cultures [13-19]. Mucins constitute the main protein components of mucus and provide a multifaceted function to the mucosal surface from which they are produced, ranging from lubrication to cell signaling to forming protective physical barriers against chemical or biological damage [4-6]. But whether or not these functions are provided by mucins alone or in association with other proteins remains an unanswered question, which we and others $[18,19]$ have attempted to address. Specifically, several reports have promoted the concept that the association between mucins and other proteins plays a vital role in defense of the respiratory and gastrointestinal mucosa against microbial infections [23-25], including an early model put forth for mucinprotein interactions in lung mucus by Rose et al. [26].

The inability to identify MUC5AC mucin by proteomic analysis may have been due to insensitivity of the detection instrumentation, incomplete trypsin digestion, a relatively low abundance of this protein, and/or failure of TCA to precipitate MUC5AC. Other proteomic studies of hAECS collected from in vitro cell cultures have demonstrated that MUC5B is the predominant mucin with much lesser amounts of MUC5AC [19]. By microarray hybridization analysis, expression of MUC1 and MUC5B mucins, but not MUC5AC, were up-regulated during ALI culture of human bronchial epithelial cells [27]. Therefore, these or other technical artifacts are the most likely explanation for the current result given that MUC5AC was clearly present in the hAECS by Western blot analysis and the fact that our prior study identified human MUC5AC in the spent culture medium of A549 lung epithelial cells and rat Muc5ac in apical washings of primary tracheal epithelial cell cultures at an ALI [28]. 

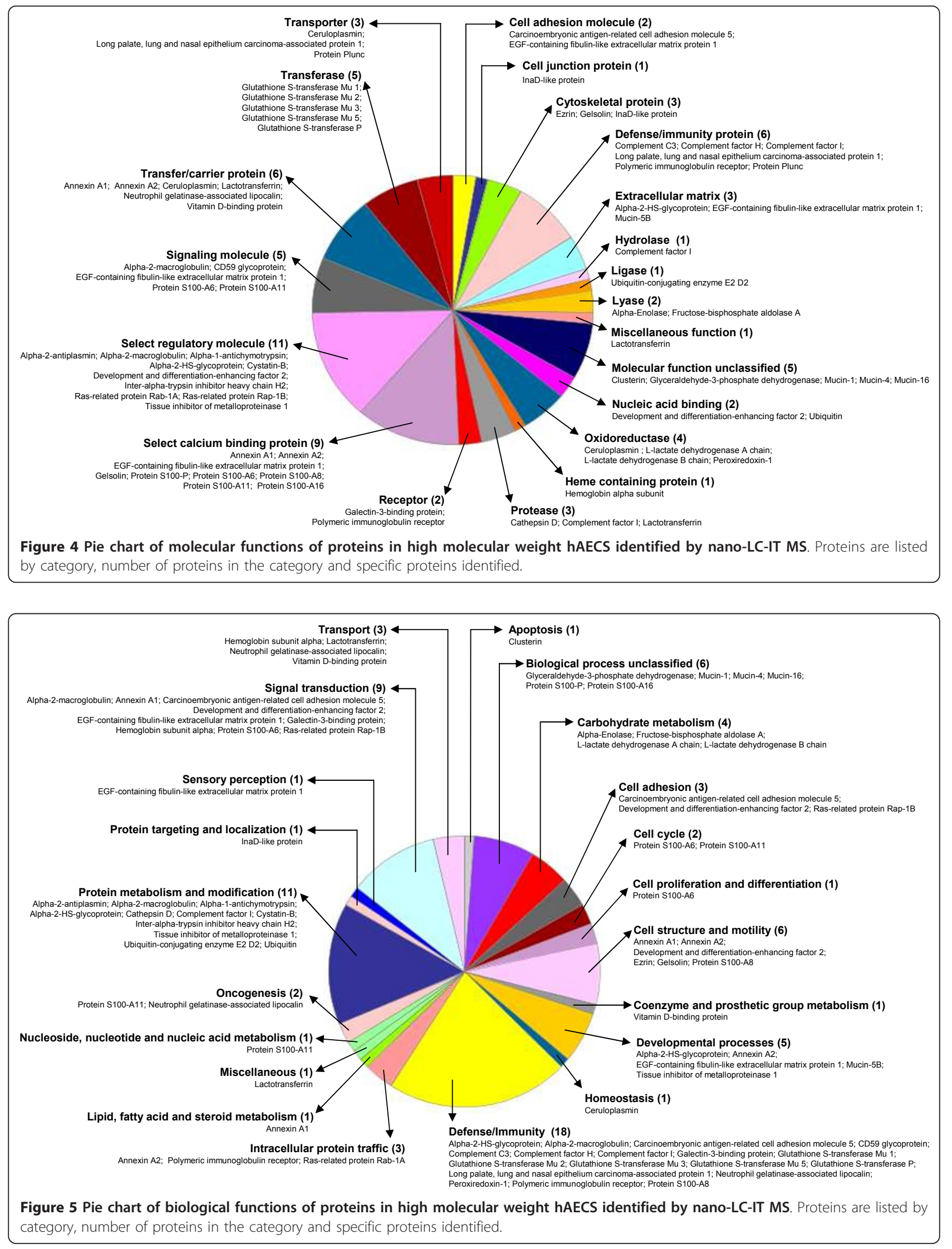


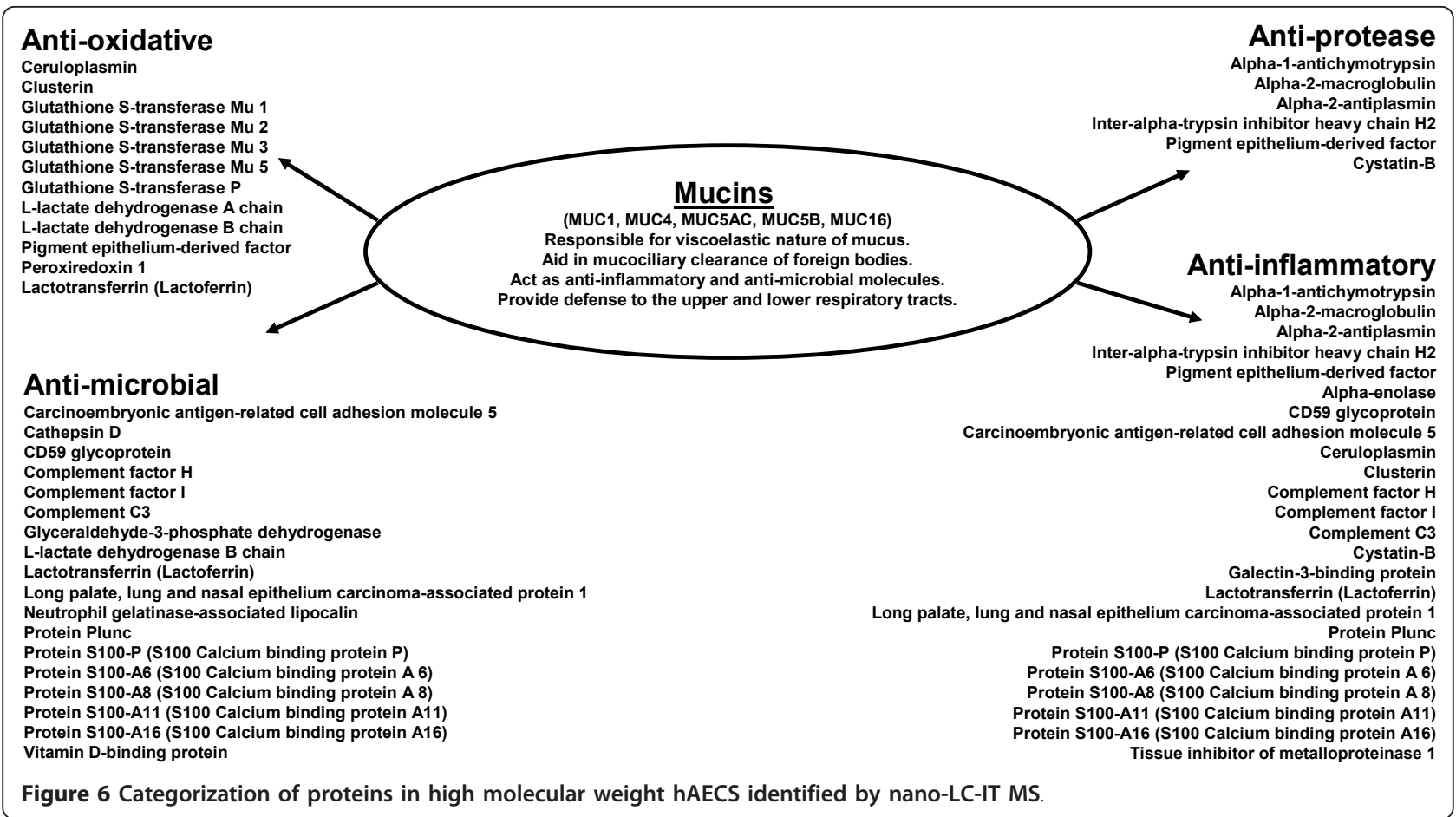

The family of proteins identified in this study were categorized according to molecular and biological functions by Pather analysis. According to the original definitions of Gene Ontology by Ashburner et al. [29], molecular function is defined as the elemental activity of a gene product at the molecular level, such as binding or catalysis, while a biological function refers to the collected operations or sets of molecular events with a defined beginning and end, and pertinent to the functioning of integrated living units (cells, tissues, organs, and organisms). A biological function is accomplished via one or more ordered assemblies of molecular functions. In this study, the molecular functions associated with the greatest number of proteins that were identified in the high molecular weight fraction of the hAECS samples were regulatory (11 proteins), calcium binding (9 proteins), transfer/carrier (6 proteins), and defense/ immunity (6 proteins). The biological functions associated with the greatest number of proteins were defense/immunity (18 proteins), protein metabolism and modification (11 proteins), and signal transduction (9 proteins). As noted above, some of these functions have been previously ascribed to airway mucins.

In addition, this collection of proteins could be further classified into inflammatory, anti-inflammatory, anti-oxidative, and anti-microbial categories based upon search of the published literature and molecular/biological function analyses. Some of the proteins fall into more than one category because they perform more than one function. For example, protease inhibitors may act both as inflammatory and anti-inflammatory components of mucus, depending upon the context of their expression [21]. Protease inhibitors that were identified in the present study were alpha-1-antichymotrypsin, alpha-2macroglobulin, alpha-2-antiplasmin, inter-alpha-trypsin inhibitor heavy chain $\mathrm{H} 2$, pigment epithelium-derived factor, cystatin- $\mathrm{B}$, and tissue inhibitor of metalloproteinase 1 . Many of these proteins have been shown to regulate protease activities in various diseases that afflict airway epithelia [30-35].

The anti-oxidative proteins identified herein were ceruloplasmin, clusterin, glutathione S-transferase (GST), pigment epithelium-derived factor, peroxiredoxin 1 (Prdx1), lactate dehydrogenase, lactotransferrin, ubiquitin, and ubiquitin-conjugating enzyme E2 D2. Amongst these, GST and Prdx1 are probably the best characterized in the respiratory tract. GST provides redox balance in response to production of reactive oxygen species and has been reported to be involved in host defense in the lung [36]. The Prdx family of anti-oxidant enzymes reduces peroxides, lipid hydroperoxides and peroxynitrites, and the role of Prdx1 in airway inflammation has been reviewed [37]. Within the group of anti-microbial proteins, CD59 is involved in inflammatory signal transduction in T cells in response to pathogenic insults [38], while components of the complement system act as antibiotic components during host defense against bacteria that commonly infect the respiratory tract, 
including Pseudomonas aeruginosa, Klebsiella pneumoniae, and Streptococcus pneumoniae [39-41]. The palate, lung and nasal epithelial clone (PLUNC) family can be subdivided into short (SPLUNC) and long (LPLUNC) proteins [42]. In this classification, the original protein called PLUNC is now SPLUNC1, which is expressed in sub-mucosal glands of normal individuals and expression is increased in cystic fibrosis lungs, especially in the surface epithelia of the conducting airways. PLUNC was reported to protect the airway epithelial sodium channel $(\mathrm{ENaC})$ from proteolytic cleavage, to prevent respiratory infections, and to inhibit lung allergic responses [43,44]. Finally, the $\mathrm{S} 100$ series of $\mathrm{Ca}^{2+}$ binding proteins are highly expressed in neutrophils and monocytes $[45,46]$ and have been reported as anti-microbial agents against $P$. aeruginosa [47] as well as novel TLR ligands important in modulating inflammation $[45,48]$.

\section{Conclusion}

We identified 55 proteins that were present in the high molecular weight fraction of in vitro human airway epithelial cell apical secretions isolated under physiological conditions. Among the mucin gene products that were identified were MUC1, MUC4, MUC5B, and MUC16. By proteomic analysis, these proteins could be classified as inflammatory, anti-inflammatory, antioxidative, and/or anti-microbial. Given that the majority of these proteins in their monomeric form possess molecular weights far less than that selected for analysis, it is theoretically possible that they may associate with the highly sialylated and negatively charged mucins through ionic and hydrophobic interactions to form a highly ordered structural organization that may be important for maintaining the proper function of airway mucus.

\section{List of abbreviations used}

ALI: air-liquid interface; ESI: electrospray ionization; hAECS: human airway epithelial cell secretion; kDa: kiloDalton; MS: mass spectrometry; Mol Wt: molecular weight; MUC: mucin; NHBE: normal human bronchial epithelial; SDS-PAGE: sodium dodecyl sulfate-polyacrylamide gel electrophoresis

\section{Acknowledgements}

This work was supported by U.S. Public Health Service grants HL-47125 and HL-81825.

\section{Author details}

'Department of Physiology and Lung Center, Temple University School of Medicine, Philadelphia, PA, USA. ${ }^{2}$ Department of Pediatrics, University of Maryland School of Medicine, Baltimore, MD, USA. ${ }^{3}$ Department of Pharmacology and Experimental Therapeutics, Thomas Jefferson University, 1020 Locust Street, JAH 364, Philadelphia, PA 19107, USA.

\section{Authors' contributions}

MA carried out the proteomic analysis and drafted the manuscript. EPL conducted preliminary experiments and wrote the final manuscript. YP and $\mathrm{YH}$ performed the cell culture and prepared the samples. KCK conceived of the study, obtained grant funding, and participated in experimental design and coordination. All authors read and approved the final manuscript.

\section{Competing interests}

The authors declare that they have no competing interests.

Received: 3 August 2010 Accepted: 20 January 2011

Published: 20 January 2011

\section{References}

1. Rose MC, Voynow JA: Respiratory tract mucin genes and mucin glycoproteins in health and disease. Physiol Rev 2006, 86:245-278.

2. Adler KB, Li Y: Airway epithelium and mucus: intracellular signaling pathways for gene expression and secretion. Am J Respir Cell Mol Biol 2001, 25:397-400.

3. Voynow JA, Gendler SJ, Rose MC: Regulation of mucin genes in chronic inflammatory airway diseases. Am J Respir Cell Mol Biol 2006, 34:661-665.

4. Kim KC, Hisatsune A, Kim DJ, Miyata T: Pharmacology of airway goblet cell mucin release. J Pharmacol Sci 2003, 92:301-307.

5. Kim KC, Jeffery PK: Airway mucus. Eur Respir J 1997, 10:1438.

6. Kim KC, Lillehoj EP: MUC1 mucin: A peacemaker in the lung. Am J Respir Cell Mol Biol 2008, 39:644-647.

7. Kim KC, McCracken K, Lee BC, Shin CY, Jo MJ, Lee CJ, Ko KH: Airway goblet cell mucin: Its structure and regulation of secretion. Eur Respir J 1997, 10:2644-2649, 1997.

8. Moniaux N, Escande F, Porchet N, Aubert JP, Batra SK: Structural organization and classification of the human mucin genes. Front Biosci 2001, 6:D1192-D1206.

9. Rose MC, Nickola TJ, Voynow JA: Airway mucus obstruction: Mucin glycoproteins, MUC gene regulation and goblet cell hyperplasia. Am J Respir Cell Mol Biol 2001, 25:533-537.

10. Sommerhoff CP, Finkbeiner WE: Human tracheobronchial submucosal gland cells in culture. Am J Respir Cell Mol Biol 1990, 2:41-50.

11. Merten MD, Tournier JM, Meckler Y, Figarella C: Secretory proteins and glycoconjugates synthesized by human tracheal gland cells in culture. Am J Respir Cell Mol Biol 1992, 7:598-605.

12. Chopra DP, Reddy L, Gupta SK, Wan L, Mathieu PA, Shoemaker RL, Rhim JS: Differentiation of immortalized epithelial cells derived from cystic fibrosis airway submucosal glands. In Vitro Cell Dev Biol Anim 1994, 30A:539-546.

13. Kim KC: Possible requirement of collagen gel substratum for production of mucin-like glycoproteins by primary rabbit tracheal epithelial cells in culture. In Vitro 1985, 21:617-621.

14. Kim KC, Rearick Jl, Nettesheim P, Jetten AM: Biochemical characterization of mucous glycoproteins synthesized and secreted by hamster tracheal epithelial cells in primary culture. J Biol Chem 1985, 260:4021-4027.

15. Kim KC: Mucin-like glycoproteins secreted from cultured hamster tracheal surface epithelial cells: Their hydrophobic nature and amino acid composition. Exp Lung Res 1991, 17:65-76.

16. Adler KB, Winn WC Jr, Alberghini TV, Craighead JE: Stimulatory effect of Pseudomonas aeruginosa on mucin secretion by the respiratory epithelium. JAMA 1983, 249:1615-1617.

17. Wu R, Martin WR, Robinson CB, St George JA, Plopper CG, Kurland G, Last JA, Cross CE, McDonald RJ, Boucher R: Expression of mucin synthesis and secretion in human tracheobronchial epithelial cells grown in culture. Am J Respir Cell Mol Biol 1990, 3:467-478.

18. Candiano G, Bruschi M, Pedemonte N, Musante L, Ravazzolo R, Liberatori S, Bini L, Galietta LJ, Zegarra-Moran O: Proteomic analysis of the airway surface liquid: Modulation by proinflammatory cytokines. Am J Physiol Lung Cell Mol Physiol 2007, 292:L185-L198.

19. Kesimer M, Kirkham S, Pickles RJ, Henderson AG, Alexis NE, Demaria G, Knight D, Thornton DJ, Sheehan JK: Tracheobronchial air-liquid interface cell culture: A model for innate mucosal defense of the upper airways? Am J Physiol Lung Cell Mol Physiol 2009, 296:L92-L100.

20. Thomas PD, Campbell MJ, Kejariwal A, Mi H, Karlak B, Daverman R, Diemer K, Muruganujan A, Narechania A: PANTHER: A library of protein families and subfamilies indexed by function. Genome Res 2003, 13:2129-2141.

21. Ohlsson K, Sveger T, Svenningsen N: Protease inhibitors in bronchoalveolar lavage fluid from neonates with special reference to secretory leukocyte protease inhibitor. Acta Paediatr 1992, 81:757-759.

22. Hiemstra PS, Maassen RJ, Stolk J, Heinzel-Wieland R, Steffens GJ, Dijkman JH: Antibacterial activity of antileukoprotease. Infect Immun 1996, 64:4520-4524. 
23. Lamblin G, Roussel P: Airway mucins and their role in defence against micro-organisms. Respir Med 1993, 87:421-426.

24. Boat TF, Cheng PW: Epithelial cell dysfunction in cystic fibrosis: Implications for airways disease. Acta Paediatr Scand Supp/ 1989, 363:25-29.

25. Forstner G, Wesley A, Forstner J: Clinical aspects of gastrointestinal mucus. Adv Exp Med Biol 1982, 144:199-224.

26. Rose MC, Lynn WS, Kaufman B: Resolution of the major components of human lung mucosal gel and their capabilities for reaggregation and gel formation. Biochemistry 1979, 184:4030-4037.

27. Ross AJ, Dailey LA, Brighton LE, Devlin RB: Transcriptional profiling of mucociliary differentiation in human airway epithelial cells. Am J Respir Cell Mol Biol 2007, 37:169-185.

28. Lu W, Lillehoj EP, Kim KC: Effects of dexamethasone on Muc5ac mucin production by primary airway goblet cells. Am J Physiol Lung Cell Mol Physiol 2005, 288:L52-L60.

29. Ashburner M, Ball CA, Blake JA, Botstein D, Butler H, Cherry JM, Davis AP, Dolinski K, Dwight SS, Eppig JT, Harris MA, Hill DP, Issel-Tarver L, Kasarskis A, Lewis S, Matese JC, Richardson JE, Ringwald M, Rubin GM, Sherlock G: Gene ontology: Tool for the unification of biology. The Gene Ontology Consortium. Nat Genet 2000, 25:25-29.

30. Poller W, Faber JP, Weidinger S, Tief K, Scholz S, Fischer M, Olek K, Kirchgesser M, Heidtmann $\mathrm{HH}$ : A leucine-to-proline substitution causes a defective alpha 1-antichymotrypsin allele associated with familial obstructive lung disease. Genomics 1993, 17:740-743.

31. Lindmark BE, Arborelius M Jr, Eriksson SG: Pulmonary function in middleaged women with heterozygous deficiency of the serine protease inhibitor alpha 1-antichymotrypsin. Am Rev Respir Dis 1990, 141:884-888.

32. Bless NM, Smith D, Charlton J, Czermak BJ, Schmal H, Friedl HP, Ward PA: Protective effects of an aptamer inhibitor of neutrophil elastase in lung inflammatory injury. Curr Biol 1997, 7:877-880.

33. Khalil N, Corne S, Whitman C, Yacyshyn $\mathrm{H}$ : Plasmin regulates the activation of cell-associated latent TGF- $\beta 1$ secreted by rat alveolar macrophages after in vivo bleomycin injury. Am J Respir Cell Mol Biol 1996, 15:252-259.

34. Buttle DJ, Burnett D, Abrahamson M: Levels of neutrophil elastase and cathepsin B activities, and cystatins in human sputum: Relationship to inflammation. Scand J Clin Lab Invest 1990, 50:509-516.

35. Sands MF, Ohtake PJ, Mahajan SD, Takyar SS, Aalinkeel R, Fang YV, Blume JW, Mullan BA, Sykes DE, Lachina S, Knight PR, Schwartz SA: Tissue inhibitor of metalloproteinase-1 modulates allergic lung inflammation in murine asthma. Clin Immunol 2009, 130:186-198.

36. Morrison RJ, Singhal SS, Bidani A, Heming TA, Awasthi S: Glutathione Stransferases of rabbit lung macrophages. Toxicol Appl Pharmacol 1998, 148:229-236.

37. Rhee SG, Chae HZ, Kim K: Peroxiredoxins: A historical overview and speculative preview of novel mechanisms and emerging concepts in cell signaling. Free Radic Biol Med 2005, 38:1543-1552.

38. Longhi MP, Williams A, Wise M, Morgan BP, Gallimore A: CD59a deficiency exacerbates influenza-induced lung inflammation through complementdependent and -independent mechanisms. Eur J Immunol 2007, 37:1266-1274.

39. Mueller-Ortiz SL, Drouin SM, Wetsel RA: The alternative activation pathway and complement component C3 are critical for a protective immune response against Pseudomonas aeruginosa in a murine model of pneumonia. Infect Immun 2004, 72:2899-906.

40. de Astorza B, Cortés G, Crespí C, Saus C, Rojo JM, Albertí S: C3 promotes clearance of Klebsiella pneumoniae by A549 epithelial cells. Infect Immun 2004, 72:1767-1774.

41. Kerr AR, Paterson GK, Riboldi-Tunnicliffe A, Mitchell TJ: Innate immune defense against pneumococcal pneumonia requires pulmonary complement component C3. Infect Immun 2005, 73:4245-4252.

42. Rollins BM, Garcia-Caballero A, Stutts MJ, Tarran R: SPLUNC1 expression reduces surface levels of the epithelial sodium channel $(E N a C)$ in Xenopus laevis oocytes. Channels (Austin) 2010, 4:255-259.

43. Garcia-Caballero A, Rasmussen JE, Gaillard E, Watson MJ, Olsen JC, Donaldson SH, Stutts MJ, Tarran R: SPLUNC1 regulates airway surface liquid volume by protecting $\mathrm{ENaC}$ from proteolytic cleavage. Proc Natl Acad Sci USA 2009, 106:11412-11417.

44. Chu HW, Thaikoottathil J, Rino JG, Zhang G, Wu Q, Moss T, Refaeli Y, Bowler R, Wenzel SE, Chen Z, Zdunek J, Breed R, Young R, Allaire E,
Martin RJ: Function and regulation of SPLUNC1 protein in Mycoplasma infection and allergic inflammation. J Immunol 2007, 179:3995-4002.

45. Soyfoo MS, Roth J, Vogl T, Pochet R, Decaux G: Phagocyte-specific S100A8/A9 protein levels during disease exacerbations and infections in systemic lupus erythematosus. J Rheumatol 2009, 36:2190-2194.

46. Wittkowski $H$, Sturrock A, van Zoelen MA, Viemann D, van der Poll T, Hoidal JR, Roth J, Foell D: Neutrophil-derived S100A12 in acute lung injury and respiratory distress syndrome. Crit Care Med 2007, 35:1369-1375.

47. Bastonero S, Le Priol Y, Armand M, Bernard CS, Reynaud-Gaubert M, Olive D, Parzy D, de Bentzmann S, Capo C, Mege JL: New microbicidal functions of tracheal glands: defective anti-infectious response to Pseudomonas aeruginosa in cystic fibrosis. PLoS One 2009, 4:e5357.

48. Foell D, Wittkowski H, Vogl T, Roth J: S100 proteins expressed in phagocytes: A novel group of damage-associated molecular pattern molecules. J Leukoc Biol 2007, 81:28-37.

doi:10.1186/1477-5956-9-4

Cite this article as: Ali et al:: Analysis of the proteome of human airway epithelial secretions. Proteome Science 2011 9:4.

\section{Submit your next manuscript to BioMed Central and take full advantage of:}

- Convenient online submission

- Thorough peer review

- No space constraints or color figure charges

- Immediate publication on acceptance

- Inclusion in PubMed, CAS, Scopus and Google Scholar

- Research which is freely available for redistribution

Submit your manuscript at www.biomedcentral.com/submit
C) Biomed Central 